\title{
Geotechnical Management of Isolated Sustainable Alpine Communities
}

\author{
Petrit Imeraj', Maaruf Ali2,, and Gent Imeraj ${ }^{3,4}$ \\ ${ }^{1}$ Board of Directors, Albanian Alps Alliance, Shkodër, Albania \\ pimeraj@yahoo.com \\ ${ }^{2}$ Epoka University, Tiranë, Albania \\ mali@epoka.edu.al \\ ${ }^{3}$ Department of Projects, Albanian Alps Alliance, Shkodër, Albania \\ voicealps@gmail.com \\ ${ }^{4}$ Epoka University, Tiranë, Albania \\ gimeraj@epoka.edu.al \\ *Correspondence: maaruf@ieee.com
}

Received: $20^{\text {th }}$ November 2021; Accepted: 29 ${ }^{\text {th }}$ December 2021; Published: $1^{\text {st }}$ January 2022

\begin{abstract}
The Albanian Alps are situated in a mountainous block in the Northern Albania region, in the counties of Shkodër (also known as Shkodra or Gegëria) and Kukës (Kukësi). The nature of the mountainous terrain formation has led to the creation of isolated communities. The need for integrating these scattered communities into a cohesive co-operating community for area sustainability is now possible by using the Internet to link them all onto an online system. To deal with natural catastrophes, disaster management cells will be created which will serve as hubs. These hubs will be located at geographically strategic positions that will enable a predetermined geofenced region for evaluation of different disasters viz. forest fires, landslide, flooding, avalanches, the burial of villages under heavy snowfalls, etc. These cells will connect the particular case with the most appropriate disaster relief, rescue service and EMR (Emergency Medical Responder), first aid services (e.g. Green Crescent/Red Cross) and EMT (Emergency Medical Technician) personnel. The cells shall be managed by locally trained human resources with the necessary equipment to provide the monitoring/analyses and first aid assistance in case of need. The technology needed for the monitoring and geotechnical management of the isolated Alpine communities will be described. The socio-economic impact of the deployment of these technologies aiding in the sustainability of these vulnerable communities will conclude the research.
\end{abstract}

Keywords: Albanian Alps; Community Sustainability; Disaster Management; Geospatial Technology; Rural Digitalisation

\section{Introduction}

An introduction to the topography and biodiversity of the Albanian Alps (Albanian: Bjeshkët $e$ Nemunais or 'Accursed Mountains') is necessary to appreciate the importance of protecting it and those who inhabit this region. The Albanian Alps are situated in the northern part of Albania, representing the region with the highest altitude and arguably one of the most beautiful areas of the country. From a physical-geographical point of view, the Albanian Alps in the south are bordered by the Drini Valley (Fierzë-Vau i Dejës), in the east and northeast they are bordered by the Tropoja basin and in the west, they descend to the Mbi-Shkodra plain. In the north they continue outside the Albanian territory, into Montenegro and Kosova. The terrain formation view for the Alpine region of Northern Albania is shown in Figure 1, below. The Albanian Alps are distinguished by great contrasts of the surrounding alpine relief, valleys and ridges. The geographical position and the variety of geographical factors, such as the extension from low altitudes, about $600 \mathrm{~m}$ to high altitudes, over $2500 \mathrm{~m}$, the quite rugged relief, different 
orientation of mountain slopes, etc., have created diverse habitats for the growth of a developed vegetation and a very rich flora. The Alpine region is characterised by a great variety of natural habitats, such as: beech and rhubarb forests, shrubs, subalpine and alpine meadows, steep limestone slopes and level pits, gravel streams, rivers, caves, semi-caves, moisture of the soil ${ }^{1}$. A description of this valley and a typical village, Boga, of this region may be found in [1].

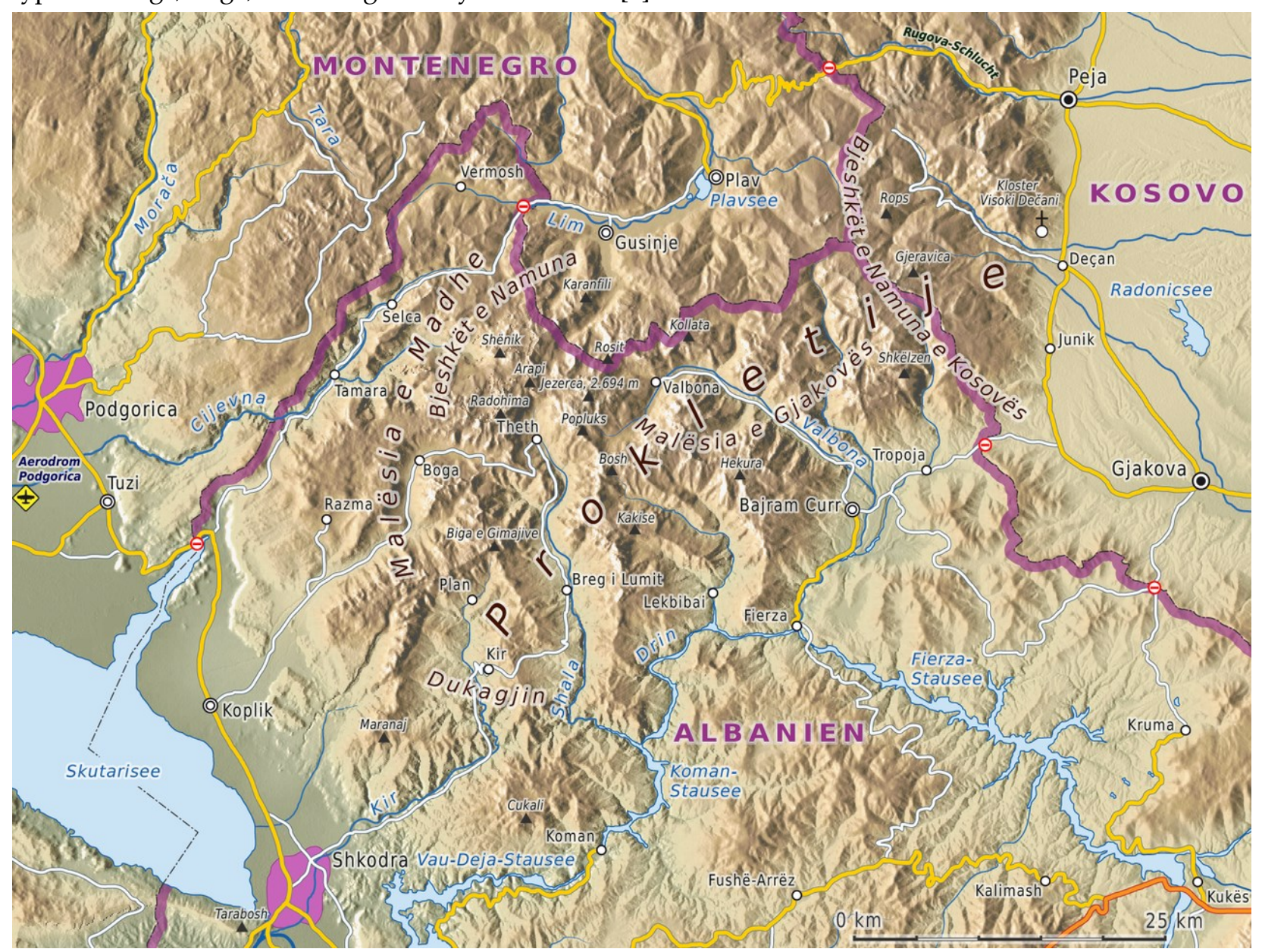

Figure 1. Map of the Bjeshkët e Nemunais or 'Accursed Mountains' (Albanian-Alps)².

\section{Review of Intervention in Albanian Alps}

\subsection{Management of Protected Areas in the Alps}

The importance of creating a park management plan is crucial for the effective maintenance of the area under jurisdiction, be it in terms of monitoring and disaster prevention. The plan is described for the study area where this research was undertaken, principally to ascertain the best way to deploy the geotechnical assistance. Since 2014, the natural parks of Albania have created their own management plans. The management plan is designed with the participation of various stakeholders at the local level. This plan is an official document which presents in written form all the park-related issues, ranging from the park's boundaries to the legal administrative base, roles, duties and responsibilities related to the management of the park. The responsible stakeholders are the: Shkodra Regional Council, Malesia e Madhe and Tropoja Municipality, local and national NGOs, various researchers, donors, potential investors (banks, businesses, etc.). As part of the administrative reform, the park management authority is the Municipality of Malesia e Madhe (Shkrel Natural Park) and Municipality of Tropoja (Natural Park Nikaj - Mertur). The municipalities are where different community issues related to regional problems are

\footnotetext{
${ }_{1}^{1}$ Wagner Production, Albania - the north, 15 August 2021. Available: https://www.youtube.com/watch?v=StKArTGNm3U\&t=1s [Accessed: 26 December 2021].

2 Tom Gonzales, "Map of the Prokletije-Mountains (Albanian-Alps)", 8 October, 2011, Available: https://commons.wikimedia.org/wiki/File:Map prokletije (de).png [Accessed: 26 December, 2021].
} 
addressed and concrete solutions are proposed. The solutions highlight the need for community involvement in decision-making and the involvement of the local government at the grassroots level ${ }^{3}$.

\subsection{Risks Threatening the Protected Areas}

In order to select the appropriate and relevant geotechnical solution to protect the Alpine region, the risks factors [2] need to be identified, whether natural or man-made. Given the current and near-future expected situation, the regional parks of Shkrel and Nikaj-Mërtur (the study areas of the research) were identified, currently under threat by some risks, which have been enumerated, analysed and discussed below:

1) Uncontrolled development of construction in the area: a practice and phenomenon that is sadly currently very prevalent in this country and region. The lack of a regulatory plan is seen as very problematic in this regard. The monitoring of unplanned building and forestry work such as cultivation can be cost effectively undertaken using UAVs (Unmanned Aerial Vehicles) [2] and other types of drones. These vehicles can be programmed to traverse regular paths on a weekly basis.

2) Fires in forests and pastures of the area: fires are considered the main threat to the natural values of the area in adversely affecting the habitat and ecosystem. Again monitoring via UAVs equipped with infra-red cameras and thermal sensors [3] can be an effective early warning system.

3) Land erosion is another major problem. It currently threatens both agricultural lands and residential areas. A lightweight hyperspectral platform that may be deployed on an UAV to monitor for land erosion is described in [4]. This solution avoids the costly use of satellites.

4) Hydropower Plant Projects (HPPs) - in the Nikaj-Mertur area, some hydropower plant (HPP) constructions are foreseen. Their construction requires amongst other things, the construction of roads and the boring of tunnels through mountains. Both of these processes significantly damage the landscape of the area. A more detailed survey and further stakeholder consultations on the environmental impacts of HPPs and the mitigation measures to be undertaken will be needed. A sustainable option to recycle the agricutural growth on hydropower plants for biomass use is presented in [5]. This additional alternative biomass fuel source will greatly aid in the sustainability goals of this region.

5) The economic development of the area is cited as a threat in itself due to the fact that the natural resources of the area can be overused. Naturally the deployment of forest rangers and other medical outposts and severe weather shelters will require the construction of 'huts'. Mori et al. [6] describes the use of 'sustainable huts' with an environmental impact assessment. These sustainable huts should be constructed in this region.

6) Destruction of the natural local flora and fauna - damage to medicinal herbs due to their overexploitation, improper collection, illegal hunting, etc. are of growing concern. Damage to the forests of the area, the constant fires and the fact that almost no one has ever been held accountable nor punished is a clear indication of the dire need to appoint forest rangers and a team of qualified staff. An effective, secure and close monitoring of the flora or fauna of interest may be adopted from the concept of e-agriculture described in [7].

7) Lack of qualified staff: Regional Nature Parks are a new development in Albania. This management poses a challenge for the current municipalities after the new administrative division in 2015. The municipality does not have the qualified staff for the management of parks. This calls for the creation of a group of specialists with management skills in the area composed of two to three people. Their concern will be to deal with the management of the park continuously. A lot of specialized training will be needed to undertake this task. Also, the municipality fails to collect the respective taxes and revenues. Residents have to pay for

\footnotetext{
${ }^{3}$ Petrit Imeraj, "Diversity of Ecosystems and Landscapes in the Mountains", Technical Session 1.1, Summer Field School Mountain Ecosystem \& Resource Management, Opening the Doors into Mountain Sustainability, 19-28 September, 2021. Accessed 27 December, 2021. [Online Video]. Available: https://www.youtube.com/watch?v=9XtcL FJNio
} 
firewood gathering, agricultural land use, livestock grazing and hunting. These new staff will need to be housed in 'sustainable huts' [6], designed to be energy efficient and self-sustaining.

8) Climate change: is expected to have their effects in the area, through the presence of extreme climatic events such as: hail, frost, snow outside the normally expected season, etc. Alpine ecosystems are deemed to be extra sensitive to climatic change and thus require careful monitoring, data collection, analysis and interpretation of the results [8].

\subsection{Socio-economic Impact of Technology on Alpine Communities}

The need for fighting corruption and good governance are two acute problems in the Northern Albania area. This does require the intervention of law-enforcers to manage the situation and the risk they may face. Specifically, these phenomena are experienced in the natural parks of Malesi e Madhe and Tropoja Municipalities. The main tasks to be undertaken and developed in these areas are: to develop a management plan for the protected areas for the strict implementation of forestry law; promotion of good governance to foster community active participation in the sustainable development process; good governance of daily affairs and general law enforcement including those related to trade, property, land and commerce. This will mean closer monitoring using surveillance technology. In the Alps, this translates to using UAVs.

The promotion of good governance in the case of the regional natural park aims at highlighting the best ecological, cultural and economic values of the area. This is can be achieved by harmonising the preservation of nature, traditions and cultural values with the development of tourism [9] based on its sustainable development. The core foundational element of the park will be sustainable development. It consists of three basic elements:

- Social development (community involvement, gender equality and local democracy);

- Environmental protection (forest management, forest protection and traditional activities);

- Economic development (jobs creation, income for the community and equitable wealth distribution).

\section{The Ecosystem of the Albanian Alps}

The Alpine nature reserve encompasses a rich and varied landscape supporting an extensive biodiverse ecosystem from the microscopic level to the macroscopic scale. An Alpine Constitution that should be drafted and written should aim to guarantee, "A healthy and ecologically suitable environment for the present and future generations; rational use of forests, water, pastures and other natural resources based on the principle of sustainable development". A constitutional guarantee justifies the efforts to manage the Alps thus avoiding major natural disasters. At the same time, the Alps often as a cross-border region, are an area of importance for the country and national security.

The great variety of natural habitats and climatic factors, the rugged alpine relief, the dominance of limestone and the alpine-karst hydrography have all helped to create very suitable conditions for a very rich flora with many endemism to flourish. About 1,700 species of plants grow in the Alpine area, which make up more than a third of the plant species of Albania. 120 species of these are endemic to the Balkans, whilst at least 50 species are sub-endemic, endemic or rare for the Albanian Alps.

The Albanian Alps are distinguished for its presence of a highly developed hydrographic network, comprising the rivers Shala, Valbona, Cemi, Vermoshi, Nikaj-Mertur, Kiri and dozens of streams and springs connected or not to these rivers. These rivers form part of the Drini and Buna basins, besides the river Cem, which is part of the watershed area of Lake Shkodra and the river Vermosh, which is part of the watershed area of the Danube ${ }^{4}$.

Eco-Development is inextricably linked to ecological tourism as an alternative for economic development. Anyone visiting the Albanian Alps or the Bjeshkët e Namuna will admire the magnificent scenic landscapes of the river valleys surrounded by the high majestic mountain ridges reaching between 2000-2500 metres high, with many deep canyons, splendid waterfalls, gushing springs, flowing crystal

${ }^{4}$ Petrit Imeraj, “Eksperti Petrit Imeraj: Turizmi alpin nisi në kushte të vështira, nevojitet rojtar institucional për mirëadministrimin", Alert.al. Available: https://alert.al/aktualitet/sociale/eksperti-petrit-imeraj-turizmi-alpin-nisi-ne-kushte-te-veshtira-nevojitet-rojtarinstitucional-per-mireadministrimin/ [Accessed: 27 December, 2021]. 
clear waters along coursing rivers surrounded by alluvial forests and colourful flowers that nourish and shelter a rich and diverse fauna.

\subsection{Demographic Situation in the Alpine Alps}

The project "Region Bjeshket e Namuna-Prokletije" is centred on the mountainous area of the Bjeshkët e Namuna. This area, which is also called the Albanian Alps and the Montenegrin Alps, geographically belongs to the Dinaric Alps. The Dinaric Alps are a large mountain chain stretching from the Julian Alps to the northern Albanian and Kosova areas. This is where the mountainous terrain sits to leave the Drinian waters and areas of Kosova. The Bjeshket e Namuna-Prokletije region has pooled mountain communities that have shared and cooperated in terms of economic development, social cohesion, services and share the same infrastructure networks [10].

The cross-border region of Bjeshket e Namuna (or Prokletije in Serbo-Croatian), straddles Albania, Kosova and Montenegro, is shown in Figure 2, below. It has several features that are common to many municipalities, regardless of the state they are a part of. Generally, in all the administrative units of this cross-border region, a low population density prevails with little employment opportunities for the local people. These municipalities also have a high level of emigration to foreign countries contributing significantly to the remittances to the local economy. In many parts of the cross-border regions, the rural areas have a much lower level of density compared to the urban areas. However, the rural population is also unevenly distributed between the lowland and mountainous areas.

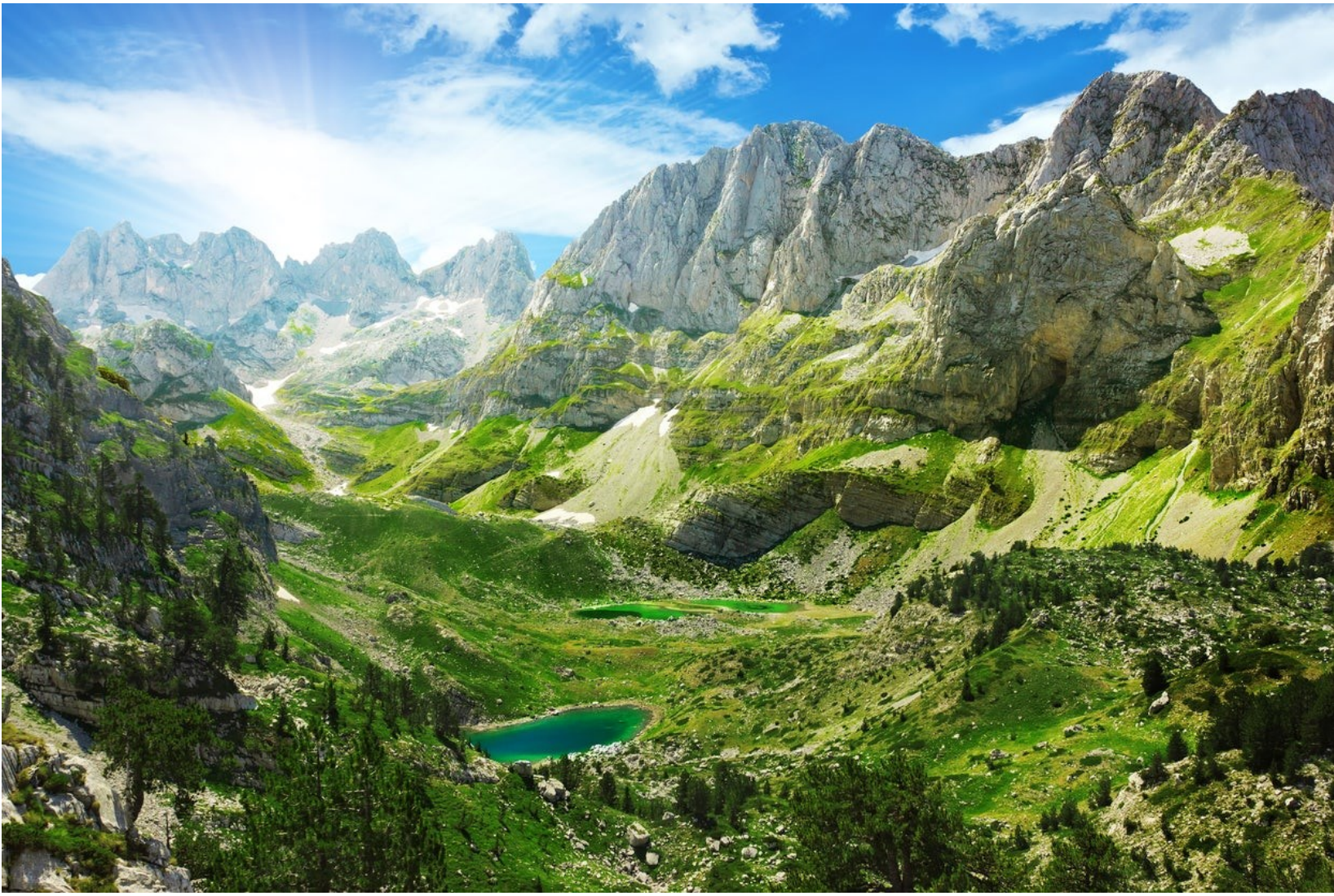

Figure 2. Bjeshket e Namuna (Prokletije in Serbo-Croatian) - the Accursed Mountains, view from the Albanian side. ${ }^{5}$

The depopulation process is more severe in the mountainous areas than in the lowland areas. The entire cross-border region has an area of $6,150 \mathrm{~km}^{2}$ with nearly half a million inhabitants (436, 912 people). The region and the population are distributed amongst these three neighbouring states: Albania - 2,484 $\mathrm{km}^{2}$ with 176,646 inhabitants; Montenegro - 1,918 km² with 38,865 inhabitants and Kosova 1,748 $\mathrm{km}^{2}$ and 221,401 inhabitants. It is difficult to find data relating to human capital in this region. The area does have a low population density. Most of the municipalities in the area have a population density of less than 30

${ }^{5}$ https://img.itinari.com/page/content/original/5ded1bd7-d4d5-4e6e-91c9-6127d650945b-prokletijealbanija.jpg?ch=DPR\&dpr=1.25\&w=994\&s=96b87e837c14497be53097b144129248 [Accessed: 27 December, 2021].

www.aetic.theiaer.org 
inhabitants $/ \mathrm{km}^{2}$. For example, the density of the population in the former municipality of Shkodra is up to 30 times lower than in the other rural areas and more than 60 times lower than in the urban areas. The lack of infrastructure, especially during the winter, the lack of training opportunities for young people and the excessive use of forests, were all among the most recurring obstacles in most of the cross-border territories. The young generations consider that the low population density in such a large mountainous territory does hamper the creation of positive development synergies for new business ventures and opportunities ${ }^{6}$.

The depopulation process, which has been happening for the last twenty years, continues to reduce the level and variety of services that can be effectively provided in the area. The consequences of this are that the number of basic or vocational education institutions and health services are limited in the mountainous areas. The persistent state of social exclusion in the area has two main dimensions:

1. economic exclusion of certain parts of the population and

2. exclusion from services - a significant part of the population still suffers from extreme poverty.

For the foregoing, there are currently no good accurate studies on the actual level of migration and human potential regarding the Albanian Alps. However, the number of families migrating to foreign countries, in the Albanian part has grown considerably in the last two to three years.

\section{Disaster Management Cells in Geo-isolated Rural Communities}

It is not always possible nor desirable for various reasons to adapt, upgrade and integrate into the digitalized contemporary world. The perceived problems, real and apparent need to be identified, isolated and mitigated as best as possible, one-by-one. Such is the problem with the isolated region of the Northern Albanian Alps. Being a rural community, geo-isolated in regard to the infrastructure, several obstacles exist for different activities that are held in this area. These obstacles are not only in the physical realm but also in the psychological domain. The isolation has come with the counterpart of "nature virginity", which nowadays has been converted to a medium-large tourist attraction site. With the increase in people visiting the area and global warming, the risk of natural disasters is present more than ever. The difficult positioning of mountain geo-monuments (tree, forest, land, rock, etc.) not reached by road, makes them potential risks for disaster areas. The use of Geographical Information Systems (GIS) to link the scattered villages with a radio-based internet to form to implement Smart Villages is described in [11]. The paper discusses this as the only economical, fastest and efficient way to connect all the isolated and disparate communities into one cohesive network to form fully working Smart Villages.

\subsection{The Objective of the Disaster Management Cell}

The aim is to outline 'a networked' algorithmic behaviour of relevant disaster management actors, with the objectives to:

- to provide a risk assessment of the North Albanian alp region to possible disasters, risk factors and natural hazards;

- to initiate the hub formation of people and equipment, capable of detecting, signalling and addressing possible risks in real-time using modern networking technologies. The current cellular mobile coverage for North Albania is shown in Figures 3-5.

- to present an integrated programmed modelling for environmental data registering and natural risk forecasting;

- to combine life skills with soft skills for the rural youth to secure ensured growth and sustainable planning utilising what the current communication technologies provide.

\footnotetext{
${ }^{6}$ The $18^{\text {th }}$ Agricultural Policy Forum, 16-18 October, 2018, Jahorina, Bosnia-Herzegovina. Available: http://seerural.org/news/the18th-agricultural-policy-forum-for-southeast-europe-will-be-held-on-the-16-18th-of-october-in-

jahorina/?fbclid=IwAR0uFjPovepJfrutJ4HHKwoUNjuLtS45ldtX98ngtevVeE6ag-1DNI6FO0o [Accessed: 27th December, 2021].
} 


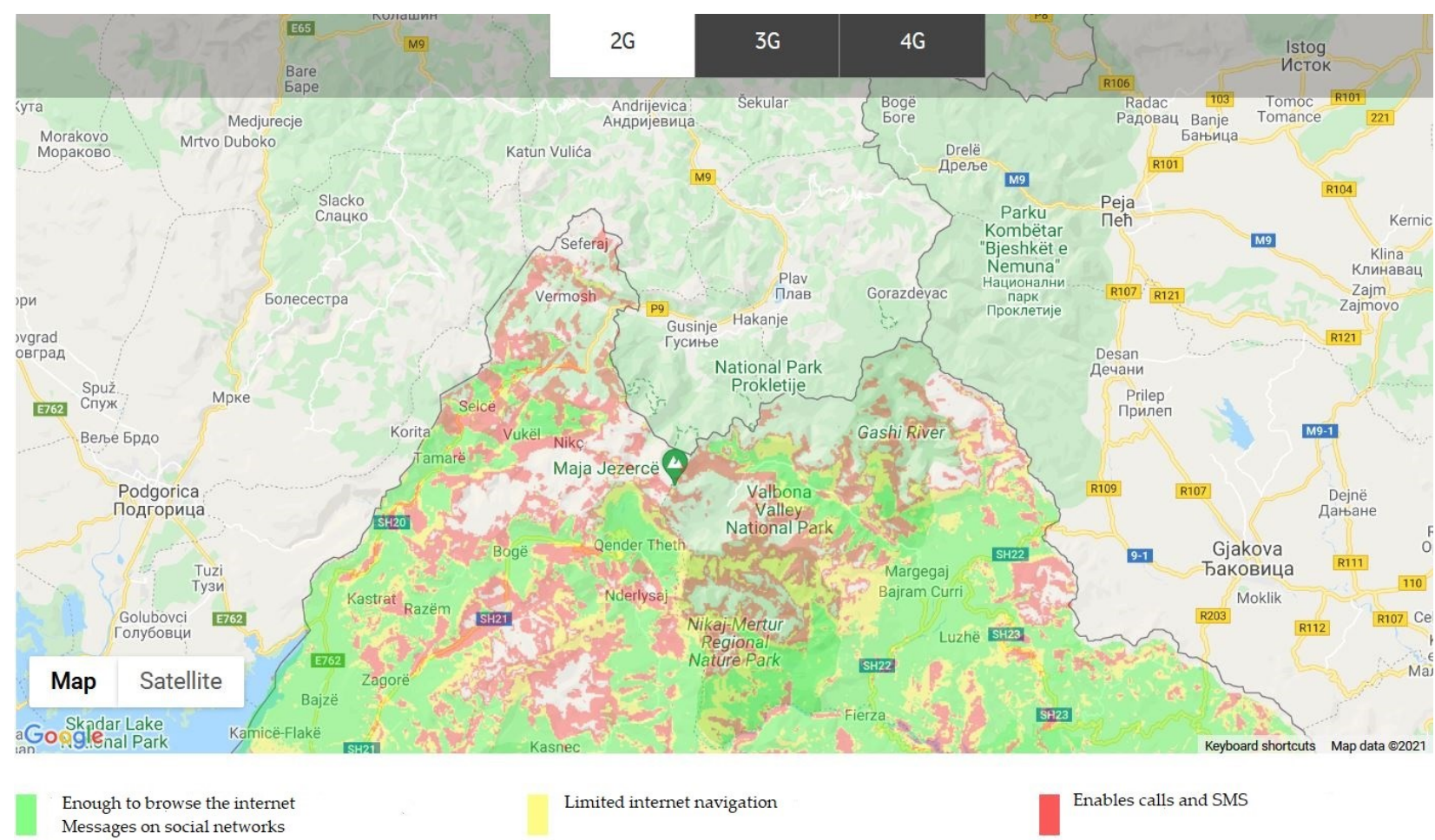

Figure 3. 2G Cellular Mobile Phone Coverage Map of Northern Albania by Vodafone.

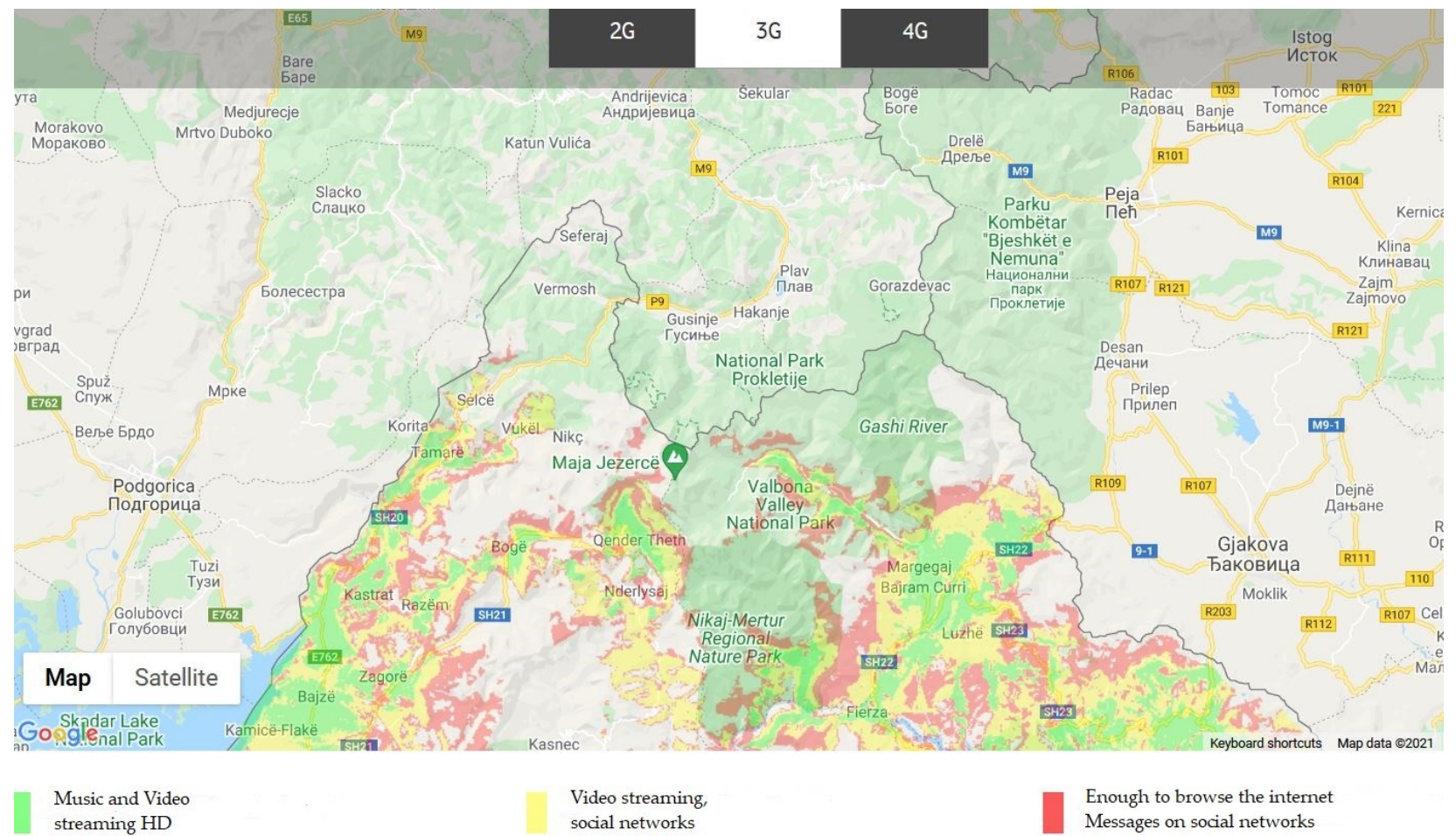

Figure 4. 3G Cellular Mobile Phone Coverage Map of Northern Albania by Vodafone ${ }^{8}$.

As can be seen in Figure 3, only 2G coverage permeates this region with partial coverage provide by 3G as shown in Figure 4. No visible 4G cellular coverage can be discerned in Figure 5 for 16 November, 2018. The coverage map shown on the mobile operator, Vodafone's website is with cellular coverage data dated 16 November, 2018, which is already three years old and was not updated when last accessed.

\footnotetext{
${ }^{7}$ https://www.vodafone.al/coverage-checker/ [Accessed: 29th December, 2021].

${ }^{8}$ Ibid.
} 


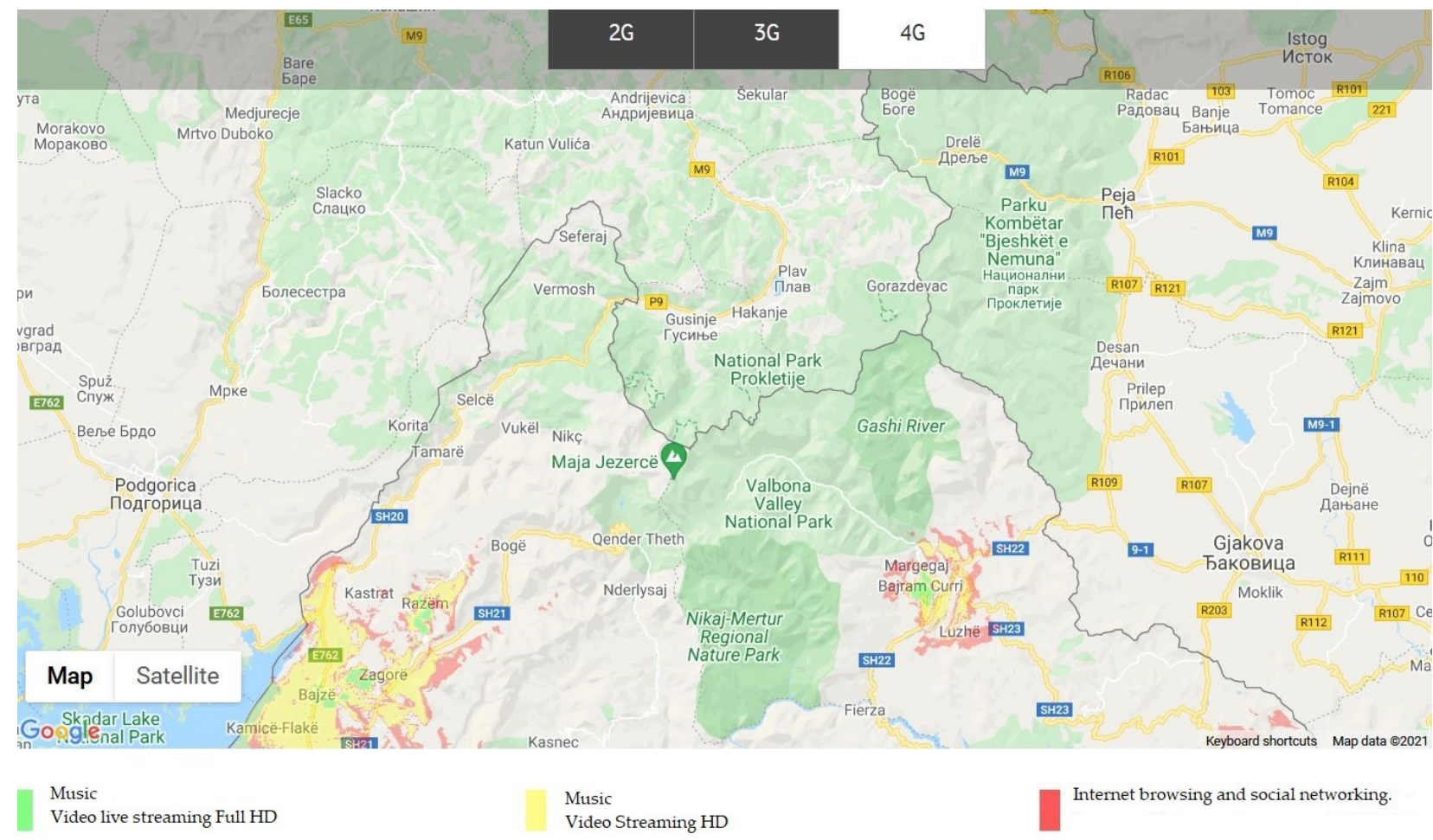

Figure 5. 4G Cellular Mobile Phone Coverage Map of Northern Albania by Vodafone ${ }^{9}$.

\subsection{Innovative Approach}

An automated system using UAVs is considered as the only possible and effective way to help autonomously manage these areas to monitor for disaster occurrence and guide relief to the appropriate sites. The flight paths of these drones and UAVs can be programmed to cover the seven valleys of the Albanian Alps, which are perpendicular to one-another. Each of these valleys has a vertical/horizontal stretch. Due to the average height of the Albanian Alps being 1,140 m with $73 \%$ of those being of the order of $600-2,000 \mathrm{~m}$ - an aerial reconnaissance method is the only viable solution for disaster management. It should also be noted that mountain features with elevations over 2,000 m make up about $7 \%$ of the overall area of the Alps also.

The solution proposed [2] is the creation of 'Disaster Management Cells', which shall be located for each valley, two per valley (at the beginning and at the end). Integrated Sensors, that measure the heat (air temperature), soil composition (moisture content, pH level) [12], land movement (seismic activity) [13] etc., will be placed on the terrain. Then UAVs will travel from one cell to the other along all the valleys. The UAV will query and upload the data from the terrain sensors and then download the data that has been collected to the second station. The forest ranger with the aid of relevant data visualisation programmes will have the information presented in such a manner so as to help understand the status of the area. Emergency situations arising such as forest fires and floods will off course set off automated alarms to the appropriate services without the intervention of a human operator.

The way the data will be acquired is circular, since by utilising sensors, the wave will propagate in circular shapes. The problem stands on how to make the most efficient space out of the circular surface acquired, to know where to place these sensors without needing to cover the same data space multiple times. The best tessellation found in nature, is the imitation of the bee honeycombs. Adopting this biomimetic strategy, the bees' hexagonal cell shape allows for obtaining the most information, with the least loss of double checking the same data. To apply this, grid computing is necessary as an infrastructure, which connects geographically distributed computers, allowing their resources to be shared. A honeycomb-based data collection system using Wireless Sensor Networks (WSNs) [14] is described in [15].

\footnotetext{
${ }^{9}$ https://www.vodafone.al/coverage-checker/ [Accessed: 29th December, 2021].
} 


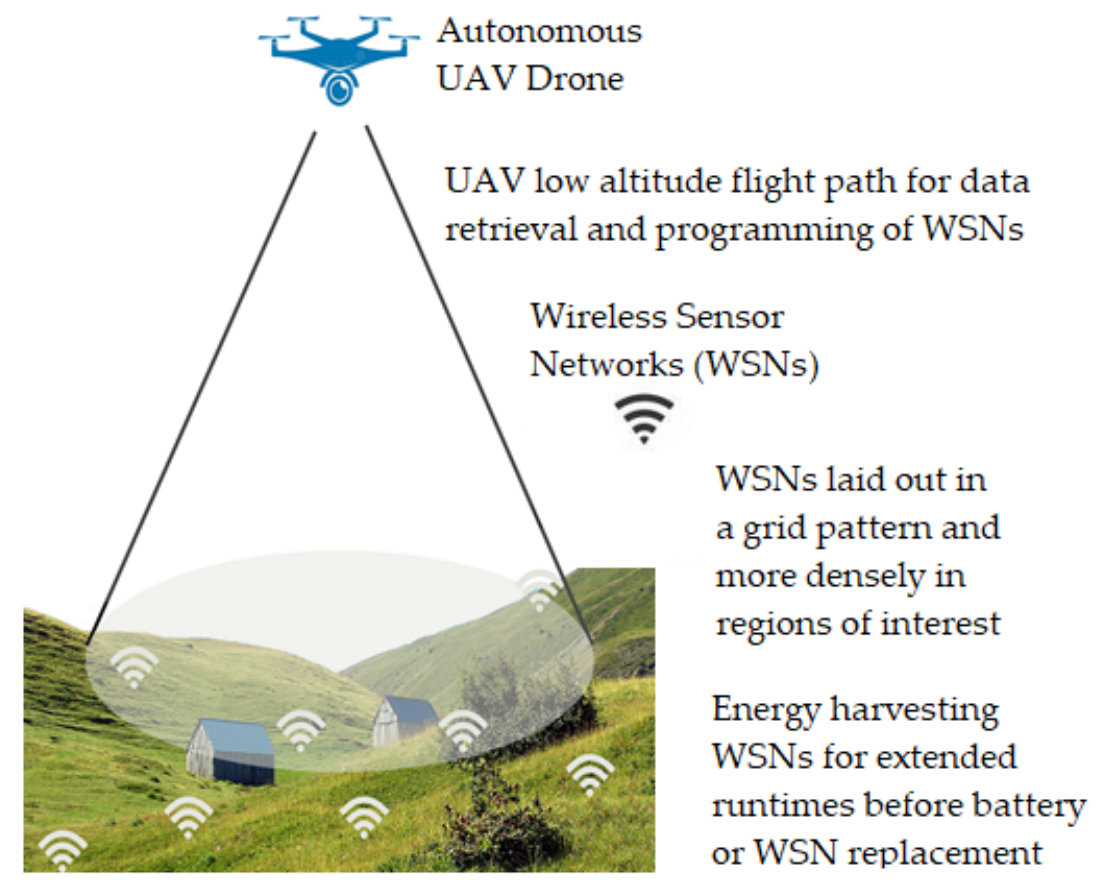

Figure 6. UAV Low Altitude Reconnaissance Flight Path for WSN Data Retrieval and WSN Programming.

\subsubsection{Schematic View}

Figure 6 and Figure 7 which was adapted from [2], outline the sequence of the UAV data gathering steps. Figure 6 shows a UAV flying low over an area to query the WSNs for data and check on their status. The bee (UAV) flies along a predicted path so as to be able to reach the connection for data retrieval from all the sensors assigned to it. If any WSN require attention for maintenance then these are reported back to the base for a field engineer to visit at a later date. The WSNs are laid out in a planned hexagonal grid structure with their density increased in regions of interest.

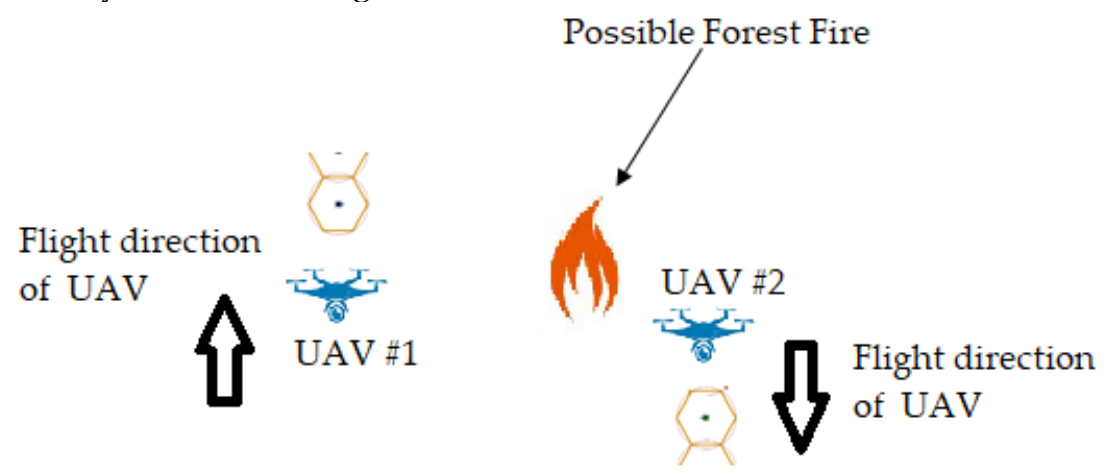

Figure 7. The Flight Paths of two UAVs over WSNs Using the Bee Search Algorithm [16] (figure adapted from [2]).

Figure 7, shows the flight path of two UAVs over terrain based WSNs. The UAVs use a Bee Search Algorithm [16], that paints a circle and a hexagon, using Radio Frequency (RF) beams, for each sensor on the ground. Note that there are two bees, which are UAVs in our case, that are flying to collect the data from the WSNs. Figure 7 shows the search pattern and the fire symbol in the area, is a possible forest fire or even an innocuous camping fire. The reasons for adopting a hexagonal grid over overlapping circles is discussed in depth in [17]. Figure 8 shows a conceptual view of the placement of two cellular communication towers at either end of a valley to give complete radio coverage without any blind spots.

This approach next needs to be trialled using real drones in the Northern Alps. This is the next phase of the research. The following section discusses the socio-economic factors to be taken into consideration in regards to an industrial geotechnical approach to be adopted in the Northern Alps whilst maximising sustainability and minimising the environmental effects. 


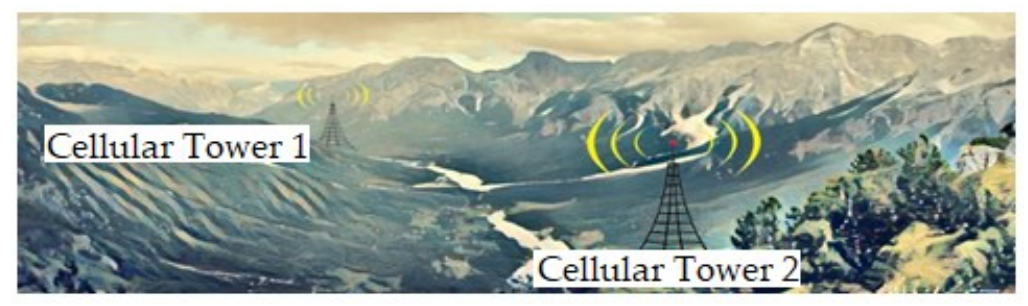

Figure 8. Disaster Management Cell Placement at both ends of a Valley ${ }^{10}$.

\section{Sustainability Considerations for a Geotechnical Engineering Solution}

Before embarking on any geotechnical engineering project with sustainability as the main focus, it is important to carefully consider the complex interaction between the four 'Es' as shown below in Figure 9. Giving importance to one ' $E$ ' will adversely affect the other 'Es'. There needs to be a fine balance and continuous monitoring of the project as it proceeds from inception to completion.

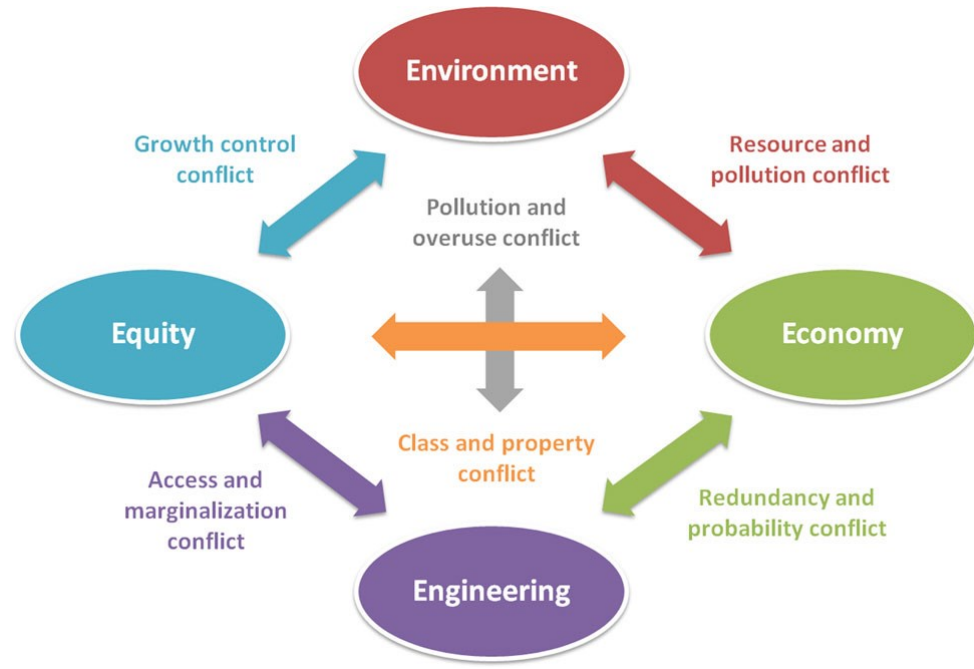

Figure 9. The Four Es of Sustainability [18].

To preserve the rustic community of the Albanian Alps, the resilience of the community must be maintained. Table 1, which is a simplified version by Kathleen Tierney in [19], originally appeared in full in [20]. It clearly shows the four properties of robustness, redundancy, resourcefulness and rapidity and how they translate into practical physical offerings for the four domains or dimensions of technical, organisational, social and economic factors. Any geotechnical project to be implemented should strongly consider the contents shown in Table 1, below.

Table 1. Qualities Needed to Ensure Resilience in any Community Project [19-20].

\begin{tabular}{|l|l|l|l|}
\hline Property/Dimension & Technical & Organisational & Social \\
\hline Robustness & $\begin{array}{l}\text { Building codes and } \\
\text { construction procedures } \\
\text { for new and retrofitted } \\
\text { structures. }\end{array}$ & $\begin{array}{l}\text { Emergency operations } \\
\text { planning. }\end{array}$ & $\begin{array}{l}\text { Social vulnerability } \\
\text { and degree of } \\
\text { community } \\
\text { preparedness. }\end{array}$ \\
\hline Redundancy & $\begin{array}{l}\text { Capacity for technical } \\
\text { substitutions. }\end{array}$ & $\begin{array}{l}\text { Alternate sites for } \\
\text { managing disaster } \\
\text { eperations. }\end{array}$ & $\begin{array}{l}\text { Availability of } \\
\text { housing options for } \\
\text { disaster victims. }\end{array}$ \\
\hline Resourcefulness & $\begin{array}{l}\text { Availability of equipment } \\
\text { and materials for } \\
\text { restoration and repair. }\end{array}$ & $\begin{array}{l}\text { Capacity to improvise, } \\
\text { innovate and expand } \\
\text { operations. }\end{array}$ & $\begin{array}{l}\text { Capacity to address } \\
\text { human needs. }\end{array}$ \\
\hline Rapidity & $\begin{array}{l}\text { System downtime, } \\
\text { restoration time. }\end{array}$ & $\begin{array}{l}\text { Time between impact } \\
\text { and early recovery. }\end{array}$ & $\begin{array}{l}\text { Time to restore } \\
\text { lifeline services. }\end{array}$ \\
\hline
\end{tabular}

\footnotetext{
${ }^{10}$ Gent Imeraj, "Risk Assessment of North Albanian Forests Probed Using UAV Integrated Computing”, Internal Research Report for Advanced Concepts in Computer Networks module for the MSc in Electronics Engineering and Digital Communication, Epoka University, Tirana, Albania. 2020-2021 Academic Year.
} 
Before the commencement of a project, the resilience assessment questions given in Table 2 [21] must be asked. Careful assessment of the answers will determine the true scope of the resiliency and impact of the geotechnical solution of implementing Smart Villages in the Albanian Alps.

Table 2. Resilience Assessment Questionnaire [21].

\begin{tabular}{|l|l|}
\hline Attribute of Resilience & Question \\
\hline General & Which functions are vital to our community within this subsystem? \\
\hline \multirow{3}{*}{ Resource Robustness } & What resources are available to perform this function? \\
\cline { 2 - 2 } & $\begin{array}{l}\text { How well does this resource perform a particular function? How well would it perform in a } \\
\text { disruption? }\end{array}$ \\
\hline & How much of this resource do we have? \\
\hline & Are there other resources available that could perform this function? \\
\hline Adaptive Capacity & $\begin{array}{l}\text { To what extent do organisations and informal social groups within this subsystem instil and } \\
\text { maintain a common memory? }\end{array}$ \\
\hline $\begin{array}{l}\text { To what extent do organisations and informal social groups within this subsystem foster a culture of } \\
\text { continuous learning and innovation? }\end{array}$ \\
\cline { 2 - 2 } & $\begin{array}{l}\text { To what extent are organisations and informal social groups within this subsystem internally and } \\
\text { externally connected? Are they loosely connected or tightly connected? How will a disturbance that } \\
\text { affects one organisation or social group impact others? }\end{array}$ \\
\hline
\end{tabular}

Figure 10, shows the DPSIR (Drivers-Pressures-State-Impacts-Responses) [22] model that should be applied to assess the impact of any proposed geotechnical project and the solutions (responses) that need to be considered to mitigate the adverse effects of the drivers, pressures and the state of the ecosystem. Table 3 [23] gives examples of the economic driving forces and Table 4 [23] gives examples of the social driving forces. Both Tables 3 and 4 give examples that are relevant to the communities of the Albanian Alps.

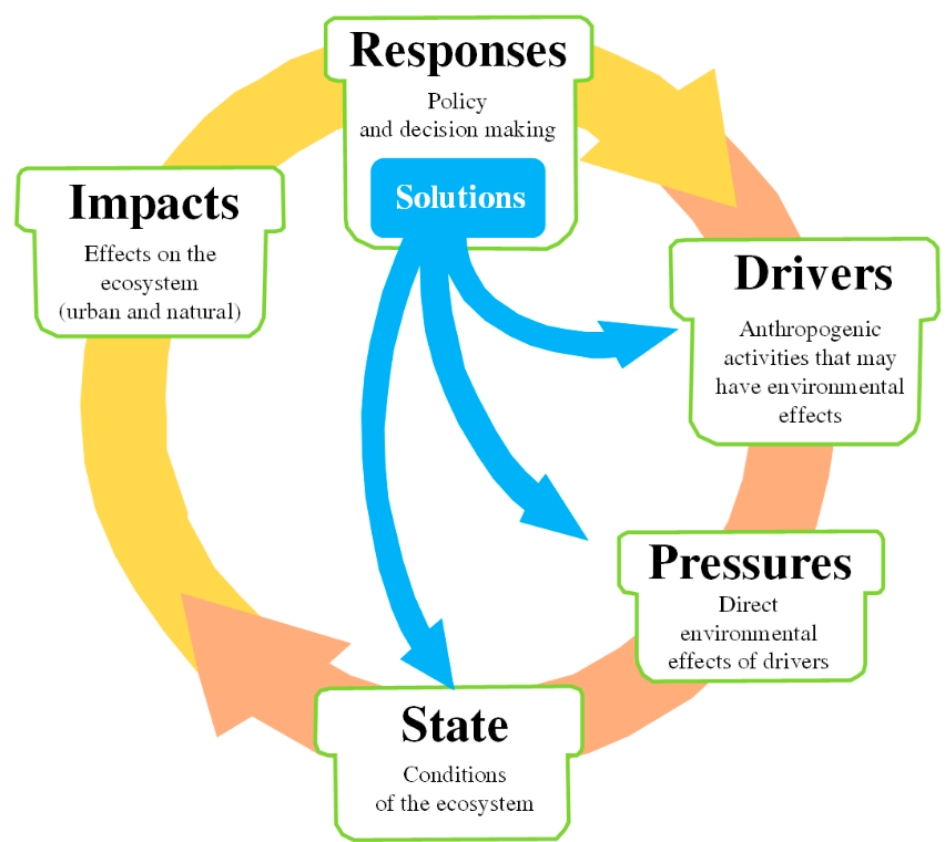

Figure 10. The DPSIR (Drivers-Pressures-State-Impacts-Responses) Framework Model [22].

Table 3. Some Examples of Economic Driving Forces [23].

\begin{tabular}{|l|l|}
\hline Human Need & Sector \\
\hline Food and Raw Materials & Agriculture, Aquaculture, Oil and Gas Extraction, Fishing, Forestry, Mining and Quarrying \\
\hline Water & Drinking Water Supply, Irrigation \\
\hline Shelter & $\begin{array}{l}\text { Housing, Textiles and Apparel } \\
\text { Medical Care, Pharmaceuticals, Social Assistance (e.g. Child Care Centres), Waste Management (e.g. } \\
\text { Sewage Treatment, Facilities and Landfills) }\end{array}$ \\
\hline Culture & $\begin{array}{l}\text { Tourism and Recreation, Education, Information (e.g. Telecommunications and Scientific Research), } \\
\text { Social Organisations }\end{array}$ \\
\hline Security & National Defence, Public Administration \\
\hline Infrastructure & Manufacturing and Trade, Transportation, Construction and Civil Engineering, Utilities \\
\hline
\end{tabular}


Table 4. Some Examples of Social Driving Forces [23].

\begin{tabular}{|l|l|}
\hline Human Need & Sector \\
\hline \multirow{3}{*}{ Social Relations } & Family Dynamics \\
\cline { 2 - 2 } & Religious Affiliations \\
\hline & Social Groups \\
\hline \multirow{2}{*}{ Gquity } & Access to Education \\
\hline & Access to Healthcare \\
\hline & Access to Jobs \\
\hline \multirow{2}{*}{ Governance } & Roles of Decision-makers \\
\hline & Types of Government \\
\hline
\end{tabular}

Table 4 [23] clearly shows the importance of taking into consideration the many social dynamic forces of the fragile dwindling communities of the Albanian Alps. The human needs need to be addressed to reduce and reverse the migration outbound from the region. Equity is seen as a strong motivator to prevent depopulation.

\section{Conclusions}

The paper has presented an introduction to the Albanian Alps in terms of its ecology and habitat including its sparsely populated and isolated communities. The risks affecting the region have been enumerated. Taking the consideration of protecting the habitat and its community with the least environmental impact, a geotechnical solution has been proposed to make the isolated communities become Smart Villages. The geotechnical solution offered is the integration of the isolated villages to the Internet via cellular networks. Monitoring of the region is proposed by the use of Wireless Sensor Networks (WSNs) with the aid of Unmanned Aerial Vehicles (UAVs) and Drones to both upload the data from the WSNs and to download new configuration parameters.

In the Albanian Alps in general, the current state of the habitats is somewhat better preserved, mainly due to its isolated geographical and climatic aspects. The regions sparse population density along with their poor means of subsistence, low levels of agricultural activity, livestock herding, forestry activities and sustainable handicrafts, as well as the lack of investment in park infrastructures have all led to actually preserving the habitat.

Natural hazards of any mountainous regions still exist, such as landslides, erosion from water and surface currents, avalanches, collapses of building and natural formations and fires are amongst the main hazards that accompany the Alpine region. These are associated with high environmental, economic and social costs, which still remain high, neither supported nor subsidised for residents and their economic activities. In it is in this context that any geotechnical solution needs to be deployed.

The concept of Disaster Management Cells has been proposed with the use of WSNs and UAVs being linked to the Internet via the mobile cellular network for cost effectiveness. Based on cellular coverage maps, the region has $2 \mathrm{G}$ and $3 \mathrm{G}$ coverage but not $4 \mathrm{G}$. It is still possible to implement the Smart Village goal using the pre-existing cellular network. Disaster management cells will generate employment for the locals, furthermore led to an increase in the safety of the area and better planning of eco-digital growth and sustainability. Drones have grown in popularity as a hobby as well as for industrial, commercial and military use. They should be used more extensively for farming and disaster monitoring. Future schemes could incorporate taking weather conditions into account to divert drones into areas where possible fire may start spreading. UAVs can also monitor for illegal trafficking or camp fire activities.

Any geotechnical project needs to consider both sustainability and resilience - these were discussed in depth with the main points presented in tables. Sustainability considerations were considered in regards to the four 'Es' - Environmental, Economical, Engineering and Equity. Resilience in terms of Technical, Organisational, Social and Economic factors were highlighted with the recommendation to use a resilience assessment questionnaire before commencing any project. The DPSIR (Drivers-PressuresState-Impacts-Responses) Framework Model was also introduced with the relevant economic and social driving forces tabulated, pertinent to the establishment of the Smart Village initiative for the Alpine Alps. 
Recommended activities that preserve the regional biodiversity which could lead to future disaster management should aim to:

i. Improve the management system of mountain areas, through capacity building and conservation of habitat types, biodiversity and landscape;

ii. Establish the construction of eco-sustainable-huts for shelter, staff and volunteers;

iii. Train forest park rangers to monitor the habitat and provide emergency disaster relief and coordination during major incidents;

iv. Train every village and hamlet to have a trained radio operator, e.g. ham radio operator;

v. Develop the functional and sustainable use of social, economic and ecotourism activities;

vi. Foster scientific-educational research for promotion, communication, education and awareness for the local populace.

\section{References}

[1] Kijtim Onuzi, Petrit Imeraj, Artan Lila and Ylber Muceku, "The valley and the village of Boga", Schriftenreihe der Deutschen Gesellschaft für Geowissenschaften, Heft 66, pp. 112-113, 28 May 2010. ISSN: 1860-1782. DOI: $10.1127 / \mathrm{sdgg} / 66 / 2010 / 112$.

[2] Gent Imeraj, Julian Hoxha and Maaruf Ali, “Risk Assessment of Forests Probed Using UAV Integrated Computing", in Proceedings of the 2021 International Conference on Computing, Electronics $\mathcal{E}$ Communications Engineering (iCCECE), 2021, pp. 41-47, DOI: 10.1109/iCCECE52344.2021.9534851.

[3] Baftjar Tabaku and Maaruf Ali, "Wireless Technology for Autonomous Albanian Farming and Crop Monitoring", in Proceedings of the 2020 International Conference on Computing, Networking, Telecommunications E Engineering Sciences Applications (CoNTESA), 2020, pp. 100-105, DOI: 10.1109/CoNTESA50436.2020.9302860.

[4] Juha Suomalainen, Niels Anders, Shahzad Iqbal, Jappe Franke, Philip Wenting et al., "A light-weight hyperspectral mapping system for unmanned aerial vehicles - The first results", in Proceedings of the $20135^{\text {th }}$ Workshop on Hyperspectral Image and Signal Processing: Evolution in Remote Sensing (WHISPERS), 2013, pp. 1-4, DOI: 10.1109/WHISPERS.2013.8080721.

[5] Carmen Mateescu and Dorian Marin, "Sustainable option to reduce by-side impact of agricultural growth on hydropower plants efficiency", in Proceedings of the $20207^{\text {th }}$ International Conference on Energy Efficiency and Agricultural Engineering (EEEAE), 2020, pp. 1-4, DOI: 10.1109/EEAE49144.2020.9278968.

[6] Mitja Mori, Rok Stropnik, Manuel Gutiérrez and Pedro Casero, “Toward sustainable mountain huts with environmental impact assessment of used technologies", in Proceedings of the $20197^{\text {th }}$ International Youth Conference on Energy (IYCE), 2019, pp. 8138-8143, DOI: 10.1109/IYCE45807.2019.8991581.

[7] Tea Osmëni and Maaruf Ali, "LoRa IoT WSN for E-Agriculture", Proceedings of the $4^{\text {th }}$ EAI/IAER International Conference on Emerging Technologies in Computing 2021 (iCETiC '21), 18-19 August, 2021, UK, vol. 395, pp. 85-93. Print ISBN: 978-3-030-90015-1, ISBN 978-3-030-90016-8 (eBook), ISSN 1867-8211, E-ISSN 1867-822X, DOI: 10.1007/978-3-030-90016-8_6.

[8] S. Asam, M. Callegari, L. De Gregorio, A. Jacob, C. Notarnicola, M. Zebisch, M. Matiu, A. Menzel and G. Fiore, "Spatiotemporal variations of alpine climate, snow cover and phenology", in Proceedings of the $20179^{\text {th }}$ International Workshop on the Analysis of Multitemporal Remote Sensing Images (MultiTemp), 2017, pp. 1-4, DOI: 10.1109/Multi-Temp.2017.8035222.

[9] Gillian Gloyer, Albania, Sixth Edition, Bradt, UK: Bradt Travel Guides, 7 May 2018, ISBN-13: 978-1784770785.

[10] Predrag Markovic, "Support to economic diversification of rural areas in Southeast Europe (SEDRA). Minutes from the $9^{\text {th }}$ Stakeholders' Group Meeting for the cross-border region 'Prokletije-Bjeshket e Nemuna'", Shkodra, Albania, 27th March, 2019, Available: https://seerural.org/wp-content/uploads/2019/04/Minutes-of-the-9th-SHGmeeting-Prokletije-Bjeshket-e-Namuna.pdf [Accessed: 27th December, 2021].

[11] Gent Imeraj and Betim Çiço, "Smart Villages - Geospatial Technology in Albanian Alps", in Proceedings of the 2020 International Conference on Computing, Networking, Telecommunications \& Engineering Sciences Applications (CoNTESA), 2020, pp. 94-99, DOI: 10.1109/CoNTESA50436.2020.9302856.

[12] Lia Kamelia, Yuga Setya Nugraha, Mufid Ridio Effendi and Tedi Priatna, “The IoT-Based Monitoring Systems for Humidity and Soil Acidity Using Wireless Communication", in Proceedings of the 2019 IEEE $5^{\text {th }}$ International Conference on Wireless and Telematics (ICWT), 2019, pp. 1-4, DOI: 10.1109/ICWT47785.2019.8978243.

[13] N. Germenis, P. Fountas and C. Koulamas, "Low Latency and Low Cost Smart Embedded Seismograph for Early Warning IoT Applications", in Proceedings of the $20209^{\text {th }}$ Mediterranean Conference on Embedded Computing (MECO), 2020, pp. 1-4, DOI: 10.1109/MECO49872.2020.9134088.

[14] Luís M. Borges, Fernando J. Velez and António S. Lebres, "Survey on the Characterization and Classification of Wireless Sensor Network Applications", IEEE Communications Surveys \& Tutorials, vol. 16, no. 4, pp. 1860-1890, Fourthquarter 2014, DOI: 10.1109/COMST.2014.2320073. 
[15] Wei Su and Gihwan Cho, "Honeycomb-Based Data Aggregation for Range Query in WSNs", in Proceedings of the 2010 International Conference on Communications and Mobile Computing, 2010, pp. 177-181, DOI: 10.1109/CMC.2010.156.

[16] D. T. Pham, A. Ghanbarzadeh, E. Koç, S. Otri, S. Rahim, M. Zaidi, “The Bees Algorithm - A Novel Tool for Complex Optimisation Problems", in Intelligent Production Machines and Systems, Elsevier Ltd, 2006, pp. 454-459. ISBN 9780080451572, Available: https://doi.org/10.1016/B978-008045157-2/50081-X [Accessed: 28 December, 2021].

[17] Konstantinos B. Baltzis, "Hexagonal vs Circular Cell Shape: A Comparative Analysis and Evaluation of the Two Popular Modeling Approximations". In Agassi Melikov, Ed., Cellular Networks - Positioning, Performance Analysis, Reliability, London, UK: IntechOpen Ltd., 26 April 2011, ch. 4, pp. 103-122, Print ISBN: 978-953-307-246-3, Online ISBN: 978-953-51-5519-5, DOI: 10.5772/14851. Available: https://www.intechopen.com/chapters/14752 [Accessed: 28 December, 2021].

[18] Mina Lee and Dipanjan Basu, "An Integrated Approach for Resilience and Sustainability in Geotechnical Engineering", Indian Geotechnical Journal, vol. 48, pp. 207-234, 14 February, 2018, Springer, EISSN: 2277-3347, PISSN: 0971-9555, Available: https://doi.org/10.1007/s40098-018-0297-3.

[19] T. D. O'Rourke, "Critical Infrastructure, Interdependencies, and Resilience”, The Bridge Linking Engineering and Society, vol. 37, no. 1, Spring 2007, pp. 22-29, National Academy of Engineering, USA, Available: https://www.nae.edu/File.aspx?id=7405\&v=70df971 [Accessed: 29 December, 2021].

[20] Michel Bruneau, Stephanie E. Chang, Ronald T. Eguchi, George C. Lee, Thomas D. O'Rourke et al., "A Framework to Quantitatively Assess and Enhance the Seismic Resilience of Communities", Earthquake Spectra, vol. 19, no. 4, pp. 733-752, 1 November 2003, SAGE Publishing, London, UK. ISSN: 8755-2930; Online ISSN: 1944-8201, DOI:10.1193/1.1623497

[21] Patricia H. Longstaff, Nicholas J. Armstrong, Keli Perrin, Whitney May Parker and Matthew A. Hidek, "Building resilient communities: a preliminary framework for assessment", Homeland Security Affairs, The Journal of the NPS Center for Homeland Defense and Security, vol. 4, no. 3, pp. 1-23, September 2010. Naval Postgraduate School Center for Homeland Defense and Security (CHDS), USA, ISSN: 1558-643X, Available: https://www.hsaj.org/articles/81 [Accessed: 29 December, 2021].

[22] Sabino De Gisi, Claudia Labianca, Francesco Todaro, Michele Notarnicola, "DPSIR Model", Encyclopedia, 2021 MDPI AG, Basel, Switzerland, Available: https://encyclopedia.pub/2145 [Accessed: 29 December, 2021].

[23] Patricia Bradley and Susan Yee, Using the DPSIR Framework to Develop a Conceptual Model: Technical Support Document, document: EPA/600/R-15/154, Washington, DC, USA: U.S. Environmental Protection Agency, August 2015, Available: https://cfpub.epa.gov/si/si public file download.cfm?p download id=527151\&Lab=NHEERL [Accessed: 29 December, 2021].

(C) 2022 by the author(s). Published by Annals of Emerging Technologies in Computing (AETiC), under the terms and conditions of the Creative Commons Attribution (CC BY) license which can be accessed at http://creativecommons.org/licenses/by/4.0. 